\title{
Contribution of Reading Comprehension and Reading Interest Skills to the Text Writing Exposition Skills
}

\author{
Yusiana $^{1}$, Ermanto $^{2}$, I Basri ${ }^{3}$ \\ \{yusiana531@ gmail.com ${ }^{1}$, ermanto@fbs.unp.ac.id², $\underline{\text { irfanibasri@ fbs.unp.ac.id }}$ \} \\ ${ }^{1,2,3}$ Faculty of Language and Art, Padang State University, Padang, Indonesia
}

\begin{abstract}
This research aims to describe the contribution of reading comprehension skills and reading interest together to the exposition text writing skills of class $\mathrm{X}$ high school students in Lima Puluh Kota. This research is a quantitative research using descriptive methods and correlational designs. The population of this research was 776 students of class X of Senior High Schools in Lima Puluh Kota. The sample in this research amounted to 85 students. Next, the data were analyzed by using Pearson Product Moment correlation test, multiple correlation test, $\mathrm{t}$ test, and $\mathrm{f}$ test.The results of the research is reading comprehension skills and reading interest together contribute to the writing skills of textual exhibitions. Based on the results of the research, it can be concluded that reading comprehension skills and reading interest contribute to the writing skills of exposition text students in class X of SMA Negeri in Lima Puluh Kota.
\end{abstract}

Keywords: exposition writing skills, reading interest, reading comprehension skills

\section{Introduction}

Indonesian language learning has a very important position in the 2013 Curriculum. Indonesian is used as a speaker for other subjects. Indonesian language learning has an important position because in the 2013 curriculum Indonesian language learning aims to prepare Indonesian people to have the ability to live as individuals and citizens who are faithful, productive, creative, innovative, and affective and able to contribute to the life of society, nation, state, and world civilization. Indonesian language is also used to develop the ability and reasoning skills [4]. Therefore, learning Indonesian is not only about language knowledge, but also as an actualization of usage in the academic social-cultural context.

Learning Indonesian in the 2013 curriculum is text based.Text-based Indonesian learning is the process of learning the Indonesian language carried out by students whose starting point is from understanding text to making text [3]. At the level of senior high school (SMA) class X there are five texts studied, namely: (1) the text of the observation report, (2) the text of the complex procedure, (3) the text of the exposition, (4) the text of the anecdote, (5) the text of the negotiation. The writing skills of the exposition text are listed in the 4th Core Competence (KI), which is processing, reasoning, and presenting in the realm of concrete and abstract domains related to the development of what they learn in school independently, and are able to use methods according to scientific principles. 4.2nd Basic Competence (KD), producing coherent 
exposition texts in accordance with the characteristics of the text to be made both verbally and in writing.

Based on the observation results of some students, obtained information as follows. First, students consider writing learning as a difficult thing, because students find it difficult to develop ideas into coherent writing, especially in the proper structure of the text. Secondly, students find it difficult to compile the right vocabulary. Third, students find writing activities boring. Fourth, students do not understand text functions, text structure, linguistic elements. This was revealed by [8] that writing exposition text learning has not yet yielded satisfactory results. Fifth, sources of reading about exposition texts are still lacking. Sixth, students feel lazy to read books related to exposition text writing skills. Seventh, students' understanding of reading is still lacking. Referring to the study conducted by [2], concluded that reading comprehension greatly affects one's writing skills. The better the reading skills of one's understanding, the better the writing skills they have. The success of the learning process at school can be seen from the learning outcomes obtained [6].

Through this research, it is hoped that we can find out the extent of the contribution of reading comprehension and reading interest skills to exposition text writing skills. Because, in the absence of reading comprehension skills and interest in reading skills exposition text writing has not been created as it should. Therefore, the researcher wants to examine how "The Contribution of Reading Comprehension Skills and Interest in Reading to Exposition Text Writing Skills.

\section{Research Methods}

The method used in this research is descriptive method with correlational research design. It is called descriptive method because it describes, analyzes and interprets the data in the form of numbers of the studied variables and then finds the relationship between one variable with another variable. Data is taken as it is and there is no treatment. It is said to use a correlational design because this research attempts to. According to [7] the population is all objects or subjects that are the target of research. The population in this research was the tenth grade students of state senior high schools in Lima Puluh Kota. The high schools in the Lima Puluh Kota district that have used the 2013 curriculum in the learning process are SMA N 1 Suliki sub-district, SMA N 1 Guguak sub-district, and SMA N 2 Harau sub-district. Samples are part of the number and characteristics of a population [9]. Considering the large number of population, it is necessary to do a sampling technique. Sampling is done by simple random sampling technique or simple random sampling through lottery. According to [9] it is said to be simple (simple) because the sampling of members of the population is done randomly without regard to strata that exist in that population. This simple random sampling technique is sampling from populations that are considered homogeneous. Simple random sampling, carried out by providing a population member code. Then, all the code is entered into the box, then shaken and issued according to the specified amount. And so on, until all classes in the population have sample members. The codes that come out are used as research samples. So, the samples in this study were SMA Negeri 1 Suliki sub-district, SMA Negeri 1 Guguak sub-district, and SMA Negeri 2 Harau sub-district.

This research consists of three variables, which are as follows. First, the reading comprehension skill variable as the independent variable (X1). Second, the variable read interest as the independent variable (X2). Third, the exposition text writing skill variable as the dependent variable is denoted by (Y). The type of instrument used to collect comprehension reading data is to provide an objective test (multiple choice), while to collect data on students' 
reading interest is to use a questionnaire. Furthermore, to collect data on exposition text writing skills used a performance test.

There are three research variables, namely 2 (two) independent variables (X1 and X2) and 1 (one) dependent variable (Y). The independent variable is comprehension reading skill (X1) and reading interest (X2), while the dependent variable is the exposition text writing skill (Y) of class X students of SMA Negeri in Lima Puluh Kota. The data of this study are three namely (X1) is the score reading comprehension skills test results, (X2) is the score of the reading interest questionnaire results, and (Y) is the exposition text writing skills. All three data are collected and processed based on data collection techniques and data analysis techniques.

\section{Discussion}

In this section, the research findings are explained about the contribution of reading comprehension and reading interest skills to the writing skills of exposition text students of class X SMA Negeri in Lima Puluh Kota. Based on the results of data analysis, the following research findings are obtained. First, reading comprehension skills contribute significantly to the writing skills of exposition text students of class X SMA Negeri in Lima Puluh Kota. Second, reading interest significantly contributes to the writing skills of exposition text class X SMA N in Lima Puluh Kota. Third, reading comprehension skills and reading interest together contribute significantly to the writing skills of exposition text students of class X SMA Negeri in Lima Puluh Kota.

\subsection{Contribution of Reading Reading Skills to Exposition Text Writing Skills}

Based on the results of research in class X senior high school students in Lima Puluh Kota, it is known that reading comprehension skills contribute to writing explicit text skills. This shows that the students' text writing exposition skills are influenced by their reading comprehension skills. The correlation coefficient of reading comprehension skills on exposition text writing skills is 0.62 with $\alpha 0.05$. Then, the contribution of reading comprehension skills to exposition text writing skills is $38.44 \%$. Based on the results of these calculations, it is known that the two variables have a positive relationship. It shows that the higher the students' reading comprehension skills, the better the exposition text written by students.

The contribution of mastery of reading comprehension has a simple regression equation ý $=$ $39.83+0.59 \neg \mathrm{X} 1$. Therefore, the higher the reading skills students have, the higher the value of exposition text writing skills. This is due to students 'reading comprehension skills needed to add students' insights in writing.

This finding confirms that on the one hand, comprehension reading skills contribute to exposition text writing skills, but on the other hand these findings also reveal that comprehension reading skills need to be improved. Reading comprehension skills are needed by students in the learning process so that every reading they read becomes useful knowledge and can add to their horizons. This is in accordance with the opinion of [1], reading is an important activity. Through reading activities can get ideas. This idea can be developed so that from reading comprehension skills possessed can produce writing. Reading is a process that is carried out and used by the reader to obtain the message to be conveyed by the author through the media of words / written language [10]. In a previous study conducted by [5] the achievement level of reading comprehension tests was $14.60 \%$. So, with the connection between reading comprehension skills possessed by someone with the ability to write.

Based on the research findings it can also be concluded that reading comprehension skills of class X senior high school students in Lima Puluh Kota District are already in the category 
of more than enough. The results of the analysis of each indicator of reading comprehension skills, namely (1) determine the main ideas with an average value of 60.81 are in the sufficient category, (2) determine the explanatory ideas with an average value of 73.75 are in the category of more than adequate, (3) the views of the author with an average value of 76.62 are in the good category, and (4) determine conclusions with an average value of 58.40 in the sufficient category.

Based on the results of the analysis of the four indicators of reading comprehension, the indicator that gets the lowest average value is the fourth indicator, the indicator determining the conclusion. The low value of the fourth indicator shows that students have not been able to determine the maximum conclusions in the text because of limitations in reading activities. Therefore, teachers in schools are expected to pay attention to student activities, especially in inviting students to do reading comprehension activities so that students are better trained.

\subsection{Contribution of Reading Interest in the Skills of Producing Exposition Texts}

The results of studies towards class X senior high school students in Lima Puluh Kota District showed that the correlation coefficient of reading interest was classified as more than enough. Interest in reading contributed significantly to the skills of writing text exposition, which amounted to $18.49 \%$ because tcount $>\mathrm{t}$ table $\neg$ or $4.35>1.663$. This shows that the students' writing text exposition skills are influenced by reading interest. Therefore, interest in reading must get more attention from students and teachers in senior high school in Lima Puluh Kota

The contribution of reading interest to the skill of producing exposition text has a simple regression equation ý $=32.90+0.668 \mathrm{X} 2$. This shows that the more students are interested in reading, the higher the value of exposition text writing skills is because reading interest is able to provide a strong impetus for reading so as to obtain useful information for writing activities.

Based on the research findings, it can also be concluded that the reading interest of grade $\mathrm{X}$ students of SMA N in Lima Puluh Kota Regency is in the category of more than enough. The results of the analysis of each indicator of interest in reading, namely (1) the subject's attitude towards the importance of choosing activities with an average value of 71.33 are in the category of more than enough, (2) expressions about things that are of interest with an average value of 70,79 are in the category of more than enough, (3) individual responses to things that encourage interest with an average value of 67.53 are in the category of more than enough, (4) goals to be achieved from encouragement of interest with an average value 69.45 are in the category of more than enough, and (5) techniques in achieving things of interest with an average value of 72.88 are in the category of more than enough.

Based on the results of an analysis of the five indicators of interest in reading, the indicator that gets the lowest average value is the third indicator, namely the individual's response to things that encourage interest with an average value of 67.53. Even though they are in the category of more than enough, students also need to be reminded that reading interest can add insight to the text, especially in terms of having a high awareness of reading. The teacher must also provide examples of exposition texts and other texts so that students have a high awareness of reading.

\subsection{Contributions of Reading Comprehension Skills and Interest in Reading Together to Exposition Text Writing Skills}

The results of studies towards class X senior high school students in Lima Puluh Kota regency showed that the correlation coefficient of reading comprehension skills and reading 
interest together on exposition text writing skills was quite high. Reading comprehension skills and reading interest contributed significantly to the writing skills of exposition texts, which amounted to $42.25 \%$ because Fcount> Ftable or 30.14>1.663. This shows that the skills of exposition text writing are influenced by reading comprehension skills and reading interest. Therefore, the skill of writing exposition text should get more attention from students and teachers in SMA N Lima Puluh Kota

Based on the research findings it can also be concluded that the writing skills of the exposition text of class X senior high school students in Lima Puluh Kota Regency are already in the good category. Based on the research findings, it can be seen the results of the analysis of writing exposition text of class X senior high school students in Lima Puluh Kota, the average value of students 'counts is in the good category (79.69), students' reading comprehension skills in the more than adequate category (67.12), and interests read students are in the category of more than enough (70.05).

\section{Conclusions and Suggestions}

This research describes the contribution of reading comprehension and reading interest skills to the writing skills of exposition text students in class X of SMA Negeri in Lima Puluh Kota. Based on the results of research and discussion carried out in chapter four, several conclusions can be drawn. First, the contribution of reading comprehension skills to exposition text writing skills was $38.44 \%$. The purpose of the data is that reading comprehension skills contribute $38.44 \%$ to the skills of exposition text writing, while the remaining $61.56 \%$ is influenced by other factors. This shows that reading comprehension skills contribute directly to exhibition writing text skills. Therefore, the better the reading comprehension skills, the better the students' exposition text writing skills. Conversely, the lower the reading comprehension skills, the lower the students' exposition text writing skills.

Second, the contribution of reading interest to the exposition text writing skills was $18.49 \%$. That is, interest in reading contributed to the writing skills of exposition texts by $18.49 \%$ while the remaining $81.51 \%$ was influenced by other factors. This shows that interest in reading directly contributes to writing exposition text skills. Based on the results obtained by students' interest in reading must be improved. If students' interest in reading is high, the exposition skill of writing exposition texts will also be high. Conversely, if students' interest in reading is low, their exposition text writing skills will also be low.

Third, the contribution of reading comprehension and reading interest to the exposition text writing skills was $42.25 \%$. That is, reading comprehension skills and reading interest together contribute to the writing skills of exposition texts by $42.25 \%$, while the remaining $57.75 \%$ are influenced by other variables. This shows directly that reading comprehension skills and reading interest together contribute directly to the writing skills of exposition text students of class $\mathrm{X}$ SMA N in Lima Puluh Kota. Students who have good reading comprehension and interest in reading skills can certainly improve their students' exposition text writing skills, although there are still many other variables that affect the exposition text writing skills.

Based on the results of the research, the following things are suggested. First, students should increase activities in reading, especially in terms of reading comprehension. This is done so that students gain a lot of knowledge and knowledge. They also must understand the reading they read. Furthermore, after the known contribution of reading comprehension skills to exposition text writing skills by $38.44 \%$, students should further enhance reading comprehension skills. Thus, the higher the level of student understanding, the more quality the 
writing produced. Likewise with the interest of BCA students, the higher the interest in reading, the higher the student's knowledge.

Second, teachers are expected to improve their quality of education. The teacher must be able to invite and convince students that every material contained in books, magazines and newspapers is very useful for them. In addition, although the teacher is only a facilitator, the teacher must also provide encouragement and understanding of concepts to students. So they have a clear grip on practice and feel more confident.

\section{References}

[1] A, R.: Membaca Pemahaman (Teori dan Aplikasi Pengajaran. pekan baru: Augrafika (2005).

[2] Delfianto. (2016): Kontribusi Keterampilan Membaca Pemahaman dan Penguasaan Kosakata terhadap Keterampilan Menulis Teks Tanggapan Deskriptif Siswa Kelas VII SMP Negeri Canduang Kabupaten Agam. Vol. 1, pp. 2. Jurnal Penelitian Pendidikan (2016).

[3] Isadorus.: Pembelajaran Bahasa Indonesia Berbasis Teks. Vol. 11, pp. 1. Jurnal Ilmiah Kebudayaan, (2017).

[4] Khair, U.: Pembelajaran Bahasa dan Sastra (BASASTRA. Vol. 2, pp. 1 Jurnal Pendidikan Dasar, 2, 1 (2018).

[5] Noverilan.: Kontribusi Kemampuan Membaca Pemahaman dan Motivasi belajar terhadap Keterampilan Menulis Argumentasi Siswa Kelas X SMA Negeri 4 Padang. Universitas Negeri Padang (2012).

[6] R, W.: Efektivitas metode pemberian tugas (Resitasi) berbantuan modul pembelajaran terhadap hasil belajar siswa kompetensi dasar uang dan perbankan SMA N 1 Kota Mungkid Kabupaten Magelang. Economic Education Analysis. Vol. 1, pp. 1 (2012).

[7] S, I.: Dasar-dasar Metodologi Penelitian. Malang: universitas negeri malang (2013).

[8] S, L. R.: Pengaruh Model Pembelajaran Berbasis Inkuiri terhadap Kemampuan Menulis Teks Eksposisi. Vol. 1, pp. 1. Penelitian Pendidikan (2014).

[9] Sugiyono.: Metode Penelitian Kuantitatif dan Kualitatif dan R\&D. bandung: alfabeta (20012).

[10] Tarigan, H.: Membaca: Sebagai Suatu Keterampilan Berbahasa. Bandung: Agkasa (2008).

[11] Widhiantari R 2012 Efektivitas metode pemberian tugas (Resitasi) berbantuan modul pembelajaran terhadap hasil belajar siswa kompetensi dasar uang dan perbankan SMA N 1 Kota Mungkid Kabupaten Magelang. Economic Education Analysis Jurnal , nomor 1.

[12] Khair, U.2018. Pembelajaran Bahasa dan Sastra (BASASTRA). jurnal Pendidikan Dasar Volume 2, Nomor 1, ISSN 2580-3611

[13] Isadorus, P.B.2017. Pembelajaran Bahasa Indonesia Berbasis Teks. Jurnal Ilmiah Kebudayaan SINTESIS. Volume 11, nomor 1.

[14] Tarigan, HG. (2008). Membaca: Sebagai Suatu Keterampilan Berbahasa. Bandung: Angkasa.(pp 7) 